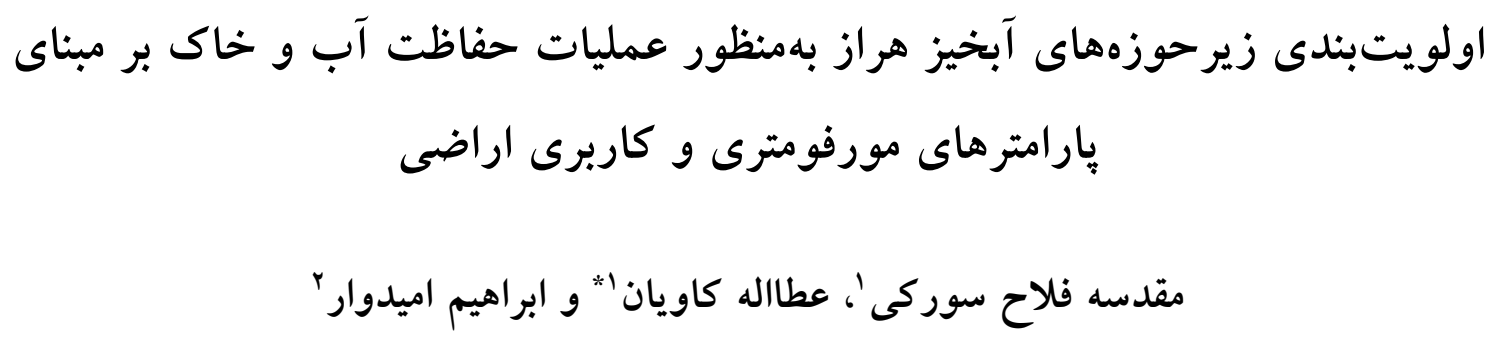

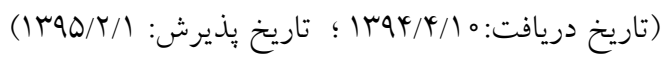

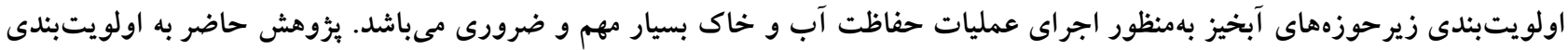

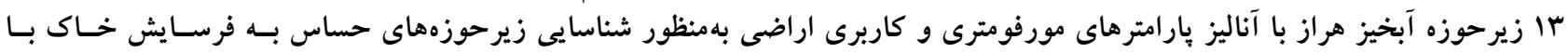

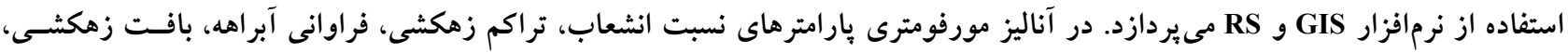

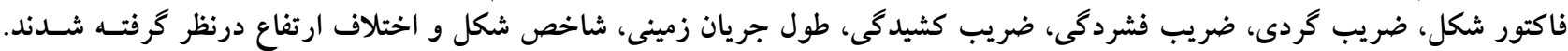

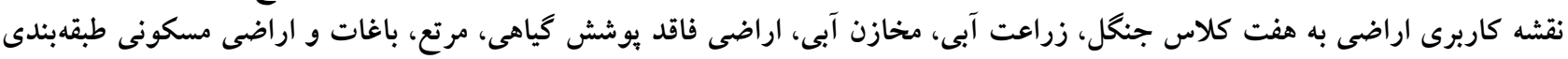

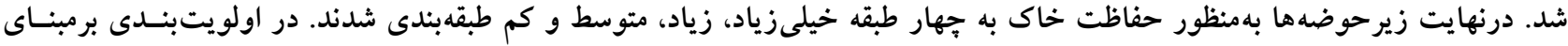

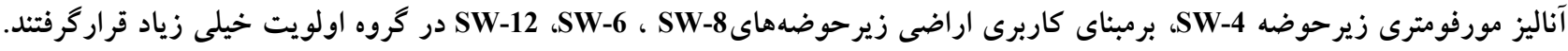

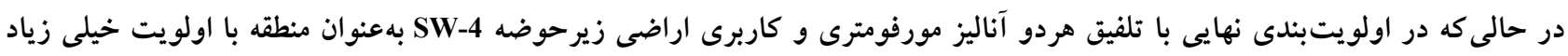

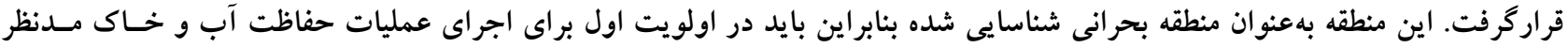
قرار بخيرد.

كليد وازه:RIS GS، حساسيت به فرسايش خاك، عمليات حفاظت

1. كروه آبخيزدارى، دانشكده منابع طبيعى، دانشخاه علوم كشاورزى و منابع طبيعى سارى

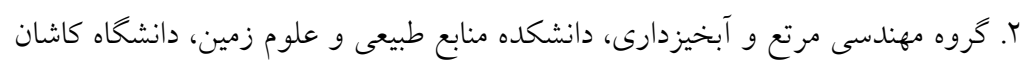

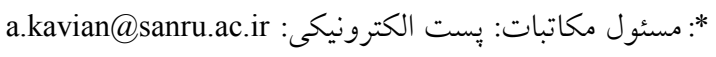


كمى موفومتريك در \& أزيرحوضه مانوت با استفاده از نرم|فـزار

GIS

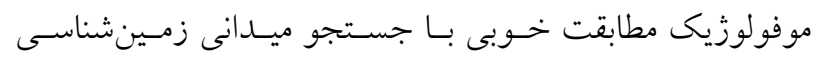

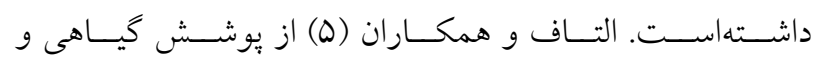

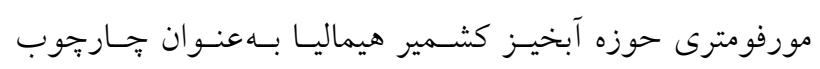

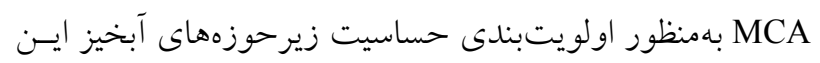

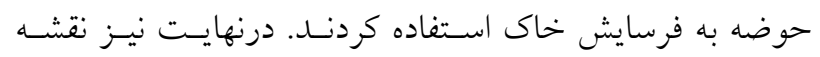
اولويتبندى را برمبناى حساسيت به فرسايش كم، متوسط، زياد

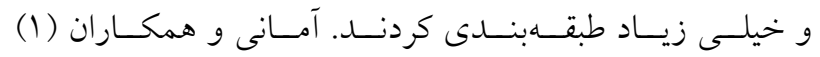

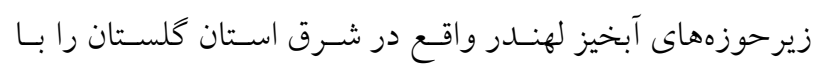

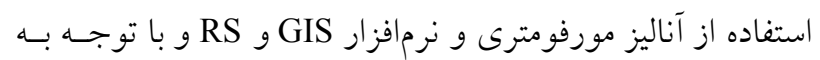

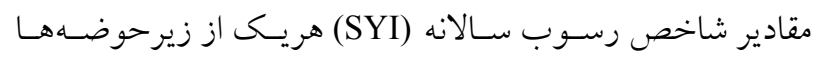

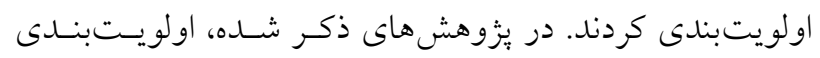

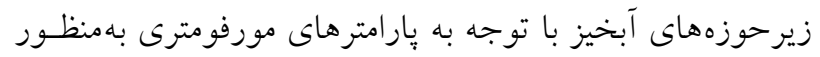

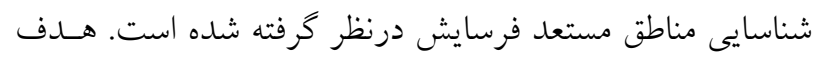

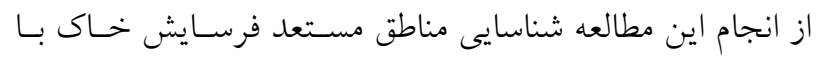

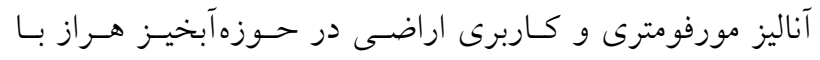

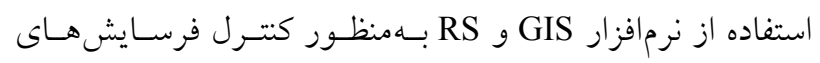

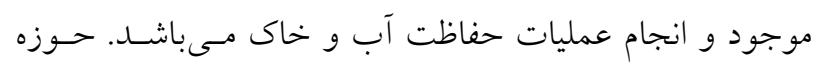

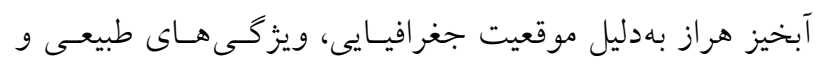
زمين شناختى يكى از مناطق مستعد فرسايش در استان مازندران

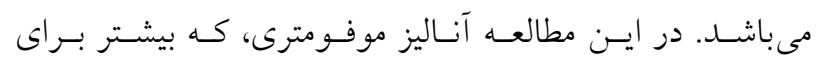

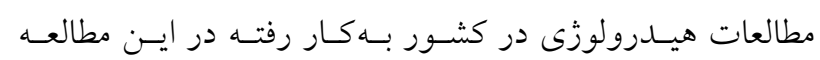

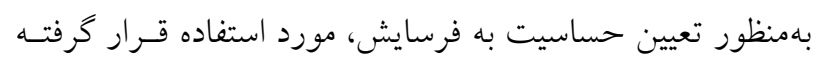

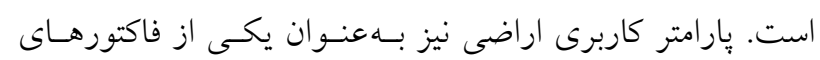

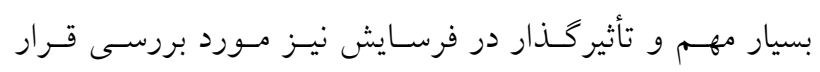
كرفتهاست.

\section{منطقه مورد مطالعه}

منطقه مورد مطالعه در جنوب شهرستان آمـل، اسـتان مازنــدران

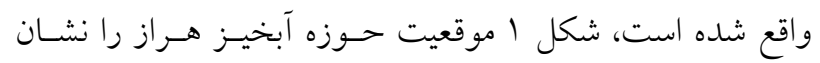

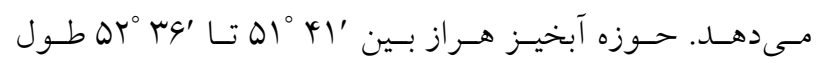

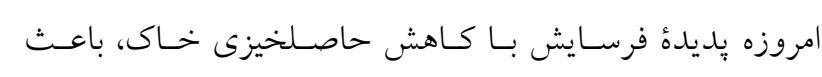

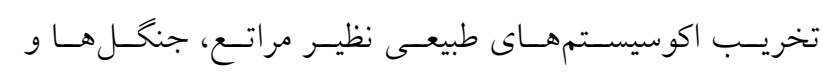

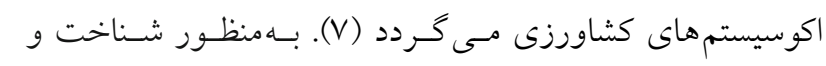
مديريت فرسايش خاك، مشخصات اراضى كه برروى فرسايش

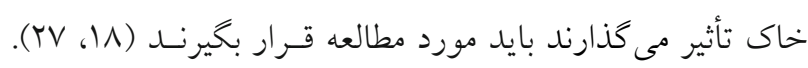

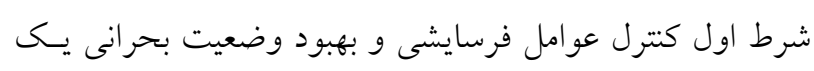

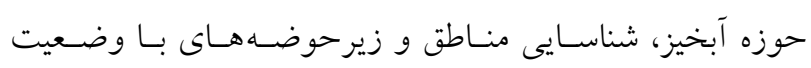

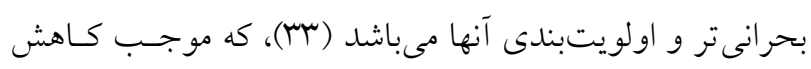

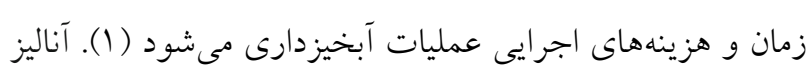

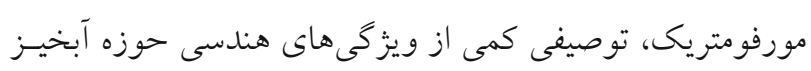

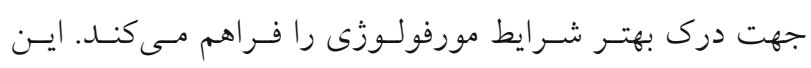

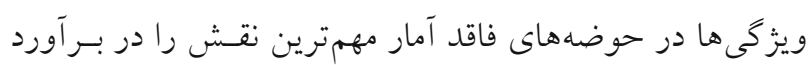

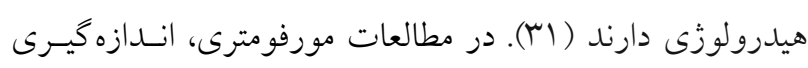

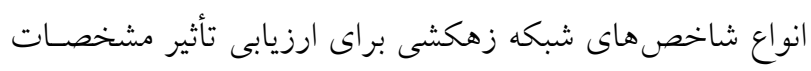

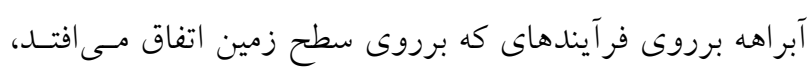

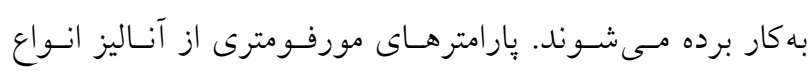
مشخصات زهكشى همجيجون ردهبندى آبراهه، مسـاحت، محسيط

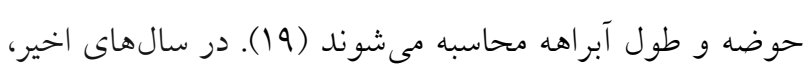

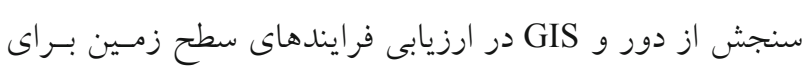

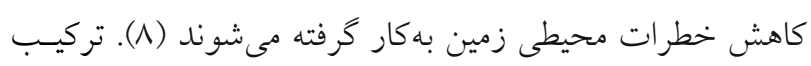

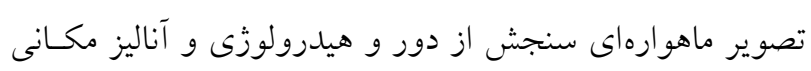

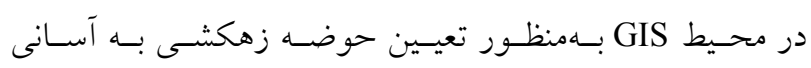

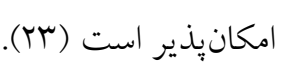

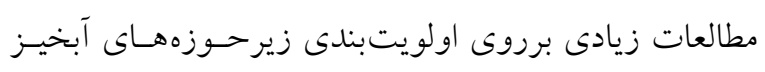

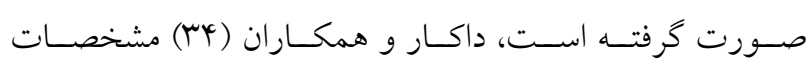

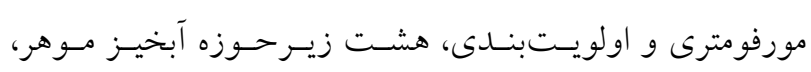

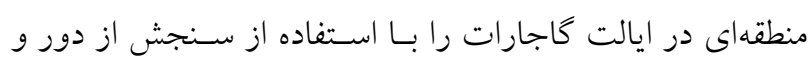
GIS

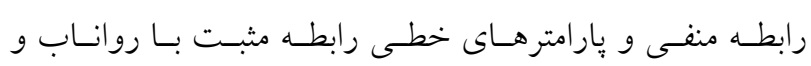

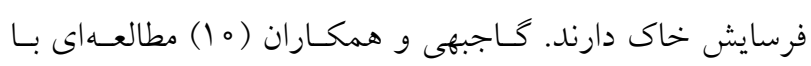
هدف شناسايى زير حوضههاى مستعد فرسايش خـاك بـا آنـاليز 


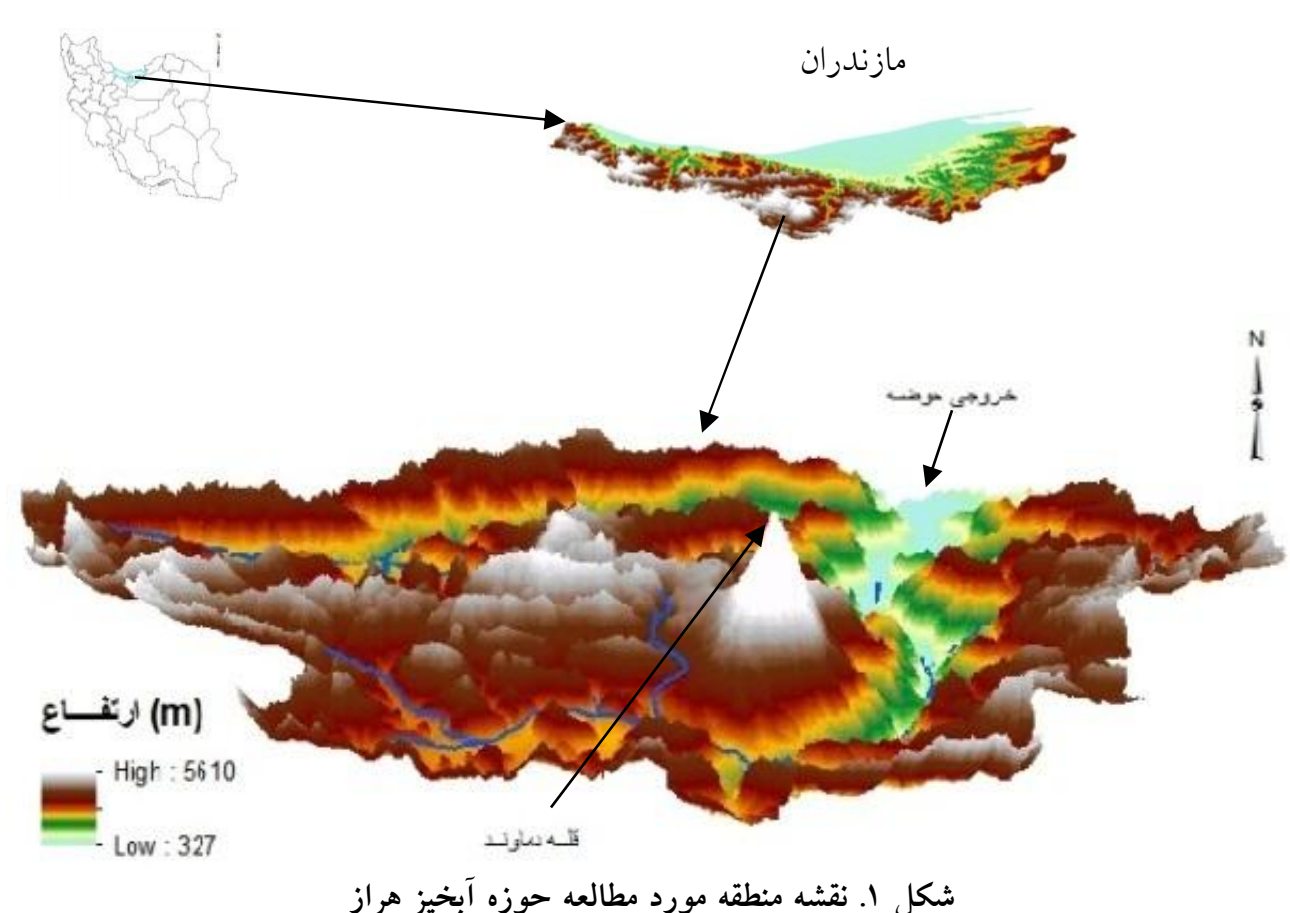

شكل ا. نقشه منطقه مورد مطالعه حوزه آبخيز هراز

و حوزهآبخيـز هـراز بــه سا زيرحسوزه آبخيـز بـهـهنـور آنـاليز موفومترى و كـاربرى اراضسى تقسـيم گرديســ. شـبكه زهكشى

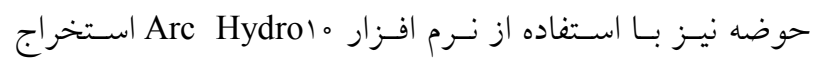
كرديد. آنـاليز مورفـومترى تمـام زيرحوضـهـهـاى ايـن سيسـتم

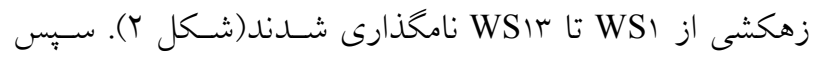

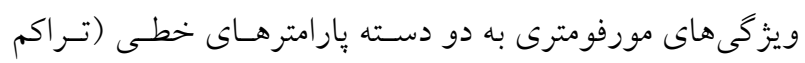

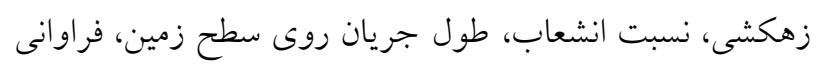
آبر اهه و بافت زهكشى) و شـكلى (نسـبت كشـيدكى، ضـريب فشردگى، ضريب گردى، شاخص شكل و فاكتور شكل) تقسيم

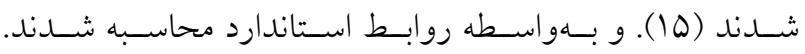
روش هاى مـورد اسـتفاده در ايسن مطالعـه در جــدول ( (1) ارائسه

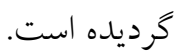
نقشه كاربرى اراضى يكى از مهمترين فاكتورهايى است كـه مقادير رواناب، تبخير و تعـرق و فرسـايش سـطحى حوضسه را تحت تأثير قرار مىدهد. پِس از تهيـهـ تصـاوير مـاهوارهاى سـال

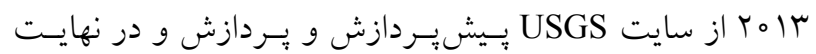
يس يردازش هايى برروى اين تصاوير بهمنظور اسـتخراج نقشـه كاربرى اراضى انجام شد. يُ از طبقهبندى تصـاوير مـاهوارهاى
شرقى و

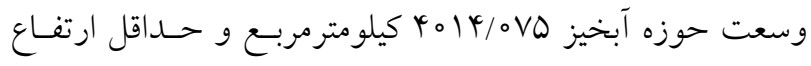

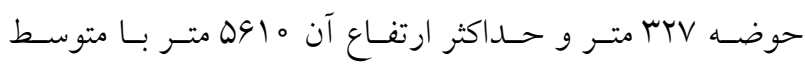
بارندگى سبو ميلى متر مىباشد. بيشـترين سـطح بوشـش حـوزه

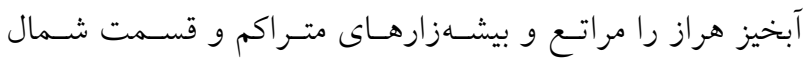

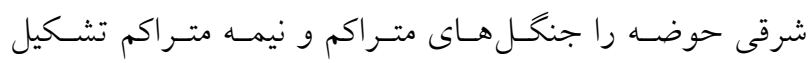
مى دهد كه بهعلت وجود رودخانه هاى متعـددى مثـل رودخانـه هراز در سراسر حوضه اطراف اين رودخانهها را كاربرى زراعت آبى و باغات تشكيل مىدهد و بهعلت وجود سلسله جبال البـرز

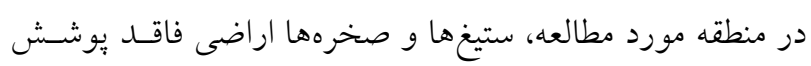
كياهى را تشكيل مى دهند.

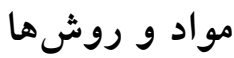

مرز حوضه منطقه مــورد مطالعـه بــا نــرمافـزار SWAT از روى

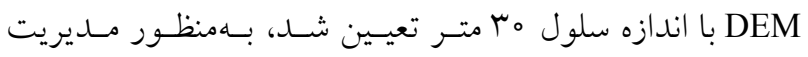
دقيقتر و اجراى راحت تر برنامههاى حفـاظتى در حسوزه آبخيـز هراز بايد اين حوضه به زيرحوضههاى كوجكىتر تقسيم مىشد، بنابراين به نرمافزار SWAT حداكثر مساحت مورد نظر داده شد 


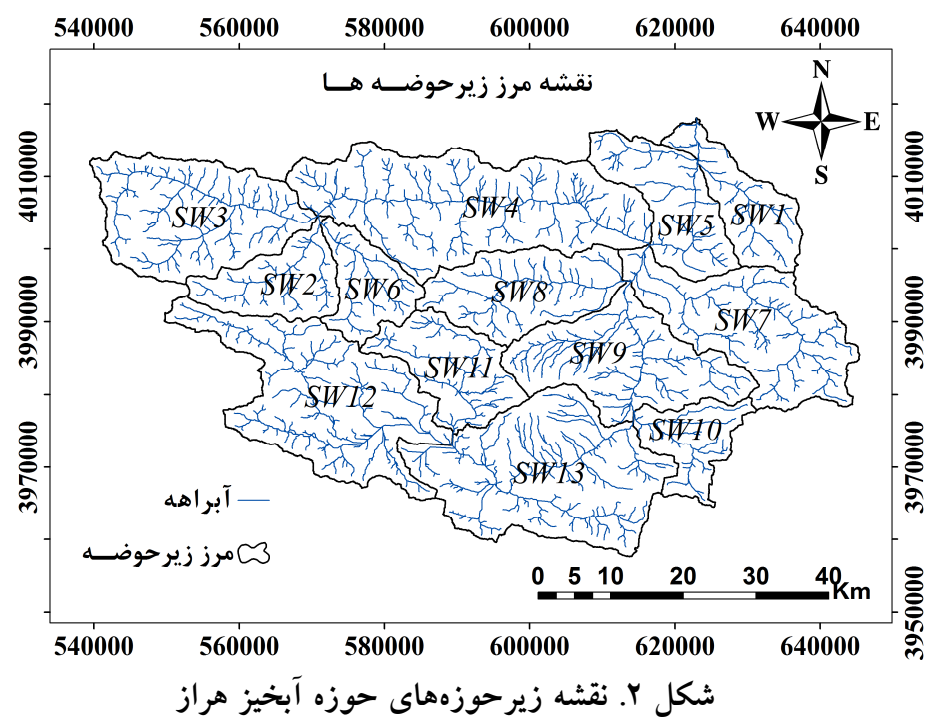

رتبههاى تمام يار امترها برحسب مقــار CP مشـخص مسىشـود

$\mathrm{Cp}=1 / \mathrm{n} \sum_{\mathrm{i}=1}^{\mathrm{n}_{1}} \mathrm{R}$

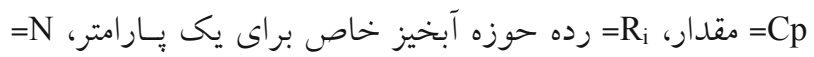
تعداد پيار امترها

\section{نتايج و بحث}

در اين مطالعه ابتدا ردهبندى آبراههها بـا روش اسـتراهلر كـه از متدوالترين روش هاى ردهبندى آبراهه است تهيه كرديــ (شـكل r). مشخصات شبكه زهكشى زيرحوزههاى آبخيز هـــاز شـامل: مساحت، محيط، طول حوضه، حداقل و حســاكثر ارتفـاع، طـول

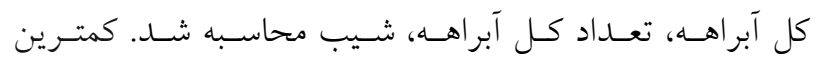

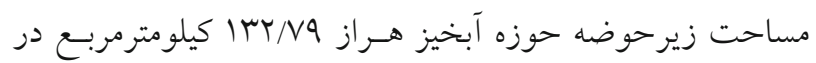
زيرحوضه ه SWI و بيشترين مساحت زيرحوزهآبخيـز ه9 كيلومترمربع مربوط به زيرحوضه SWY مئه

اولويتبندى برمبناى پارامتر مورفومترى

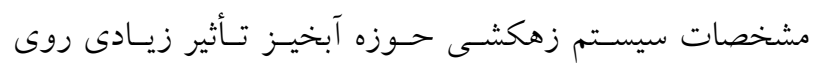
ظرفيت نقوذيذيرى و رواناب دارد (ب). يارامترهاى خطى: يار امترهاى خطى شامل بافت زهكشى عمدتاً روى ظرفيت نفوذ تأثير مى كذارد (با). تراكم زهكشى كمتر نيز
به هفت كلاس جنگل، زراعت آبى، مخازن آبسى، اراضسى فاقـد يوشش كيـاهى (اراضسى بـاير، اراضسى صـخرهاى و ...)، مرتـع،

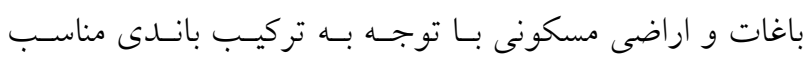
انتخاب شده با استفاده الكوريتم حداكثر احتمال، نقشـه كـاربرى

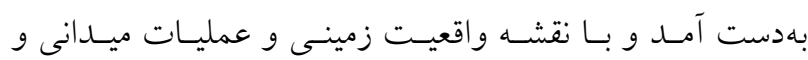
نقشه هاى توبوگر افى و برس و جو محلى ارزيابى شده و يس از تشكيل ماتريس خطا، ارزيابى صحت نتايج طبقهبنـدى براسـاس معيارهاى صحت كلسى، ضـريب كايـا، صـحت توليـد كنــده و صحت كاربر صورت كرفت.

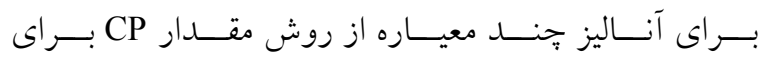
اولويتبندى حساسيت زيرحوضهها به فرسايش استفاده گرديد. اين روش برمبناى اصـول مـدلسـازى كارشناسـان اسـت (هاr). اولويستبنـــى در ايسـن روش برمبنـاى درجــه خطــر فرسـايش

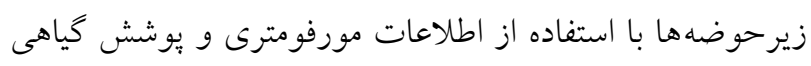

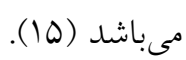
در اين روش تمام شماره رتبهها برمبناى تعـداد حـوزههـاى

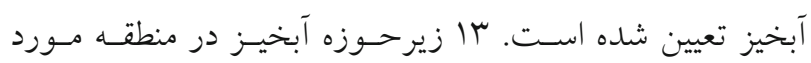

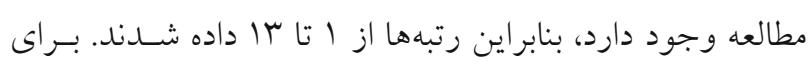
مورفومترى و يوشش كياهى، رتبه ا نشاندهنده حداكثر تـأثير و رتبه با نشاندهنده حداقل تأثير در فرسايش هسـتند. اتـر كلى لى تمام يار امترها روى قابليت فرسايش هر زيرحوضـه بـا ميـانخين 
جدول ا. فرمولهاى به كار گر فته شده براى محاسبه پارامترهاى مورفومترى

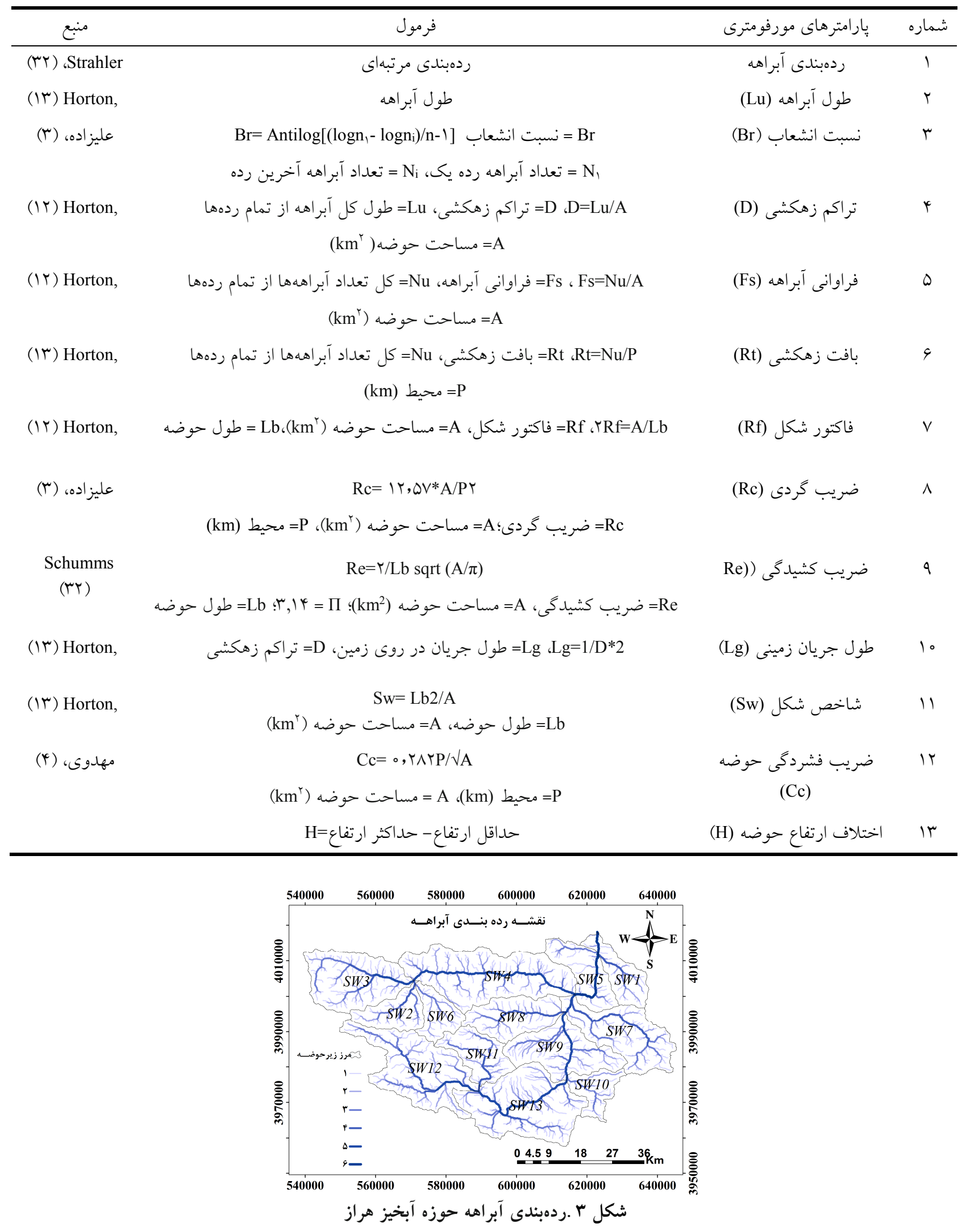


فاكتور شكل و شاخص شكل مىباشد.

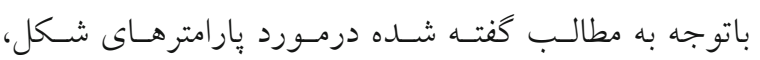

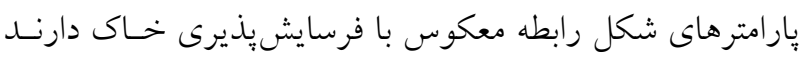

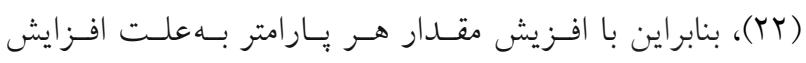
نفوذيـــيرى و كـاهش حساسـيت بـه فرسـايش رتبـه با و و

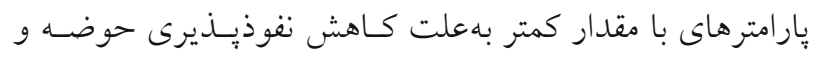

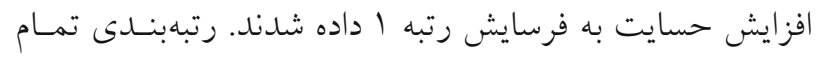

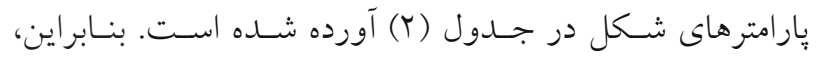

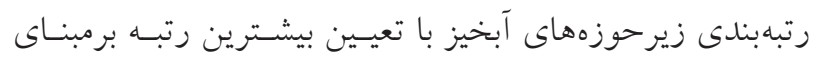
بيشترين مقدار در مورد بارامترخطى و كمترين مقــدار در مـورد يار امترهاى شكل تعيين شدند.

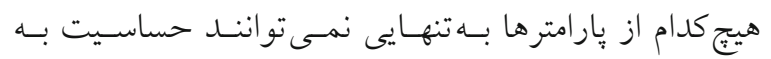
فرسايش زير حوضهها را توجيه كنند، بـهايـنمنظـور مقـدار CP براى هر يكى از زيرحوضهها، باتوجه به ميانخين رتبـهــاى داده شده به هر بارامتر محاسبه شد. زيرحوضهاى كه كمتـرين مقــدار

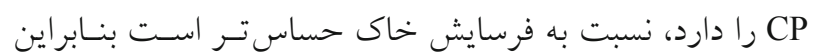

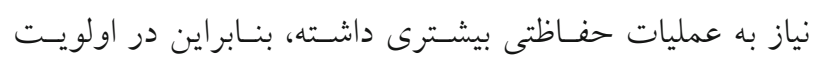

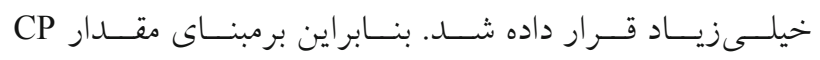

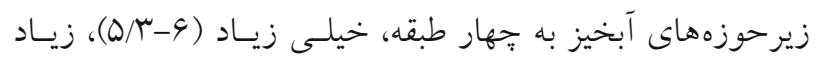
(9/I-9/V)

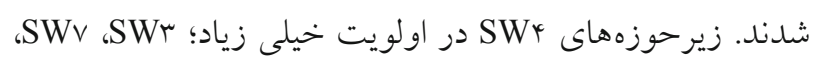

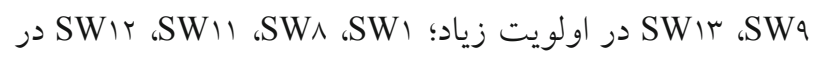

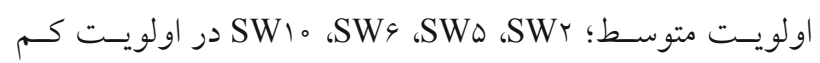

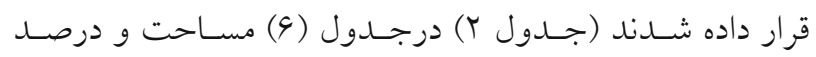

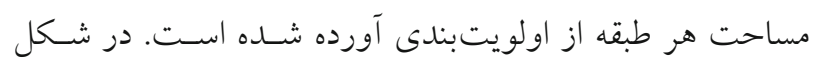

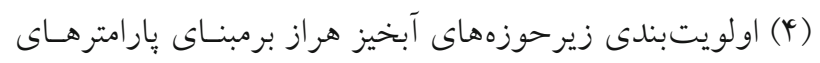
مورفومترى نشان داده شده است.

اولويتبندى برمبناى كاربرى اراضى

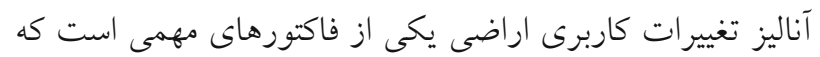

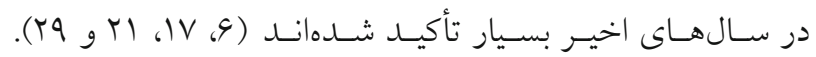

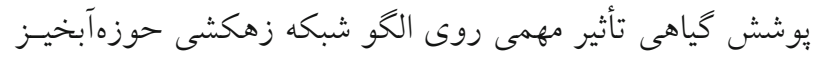

در هر زير حوزه آبخيز نشاندهنــده مـواد زيرسطحى نفوذيـذير،

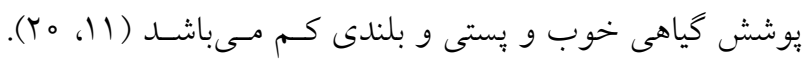

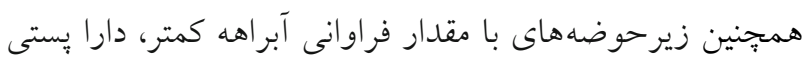

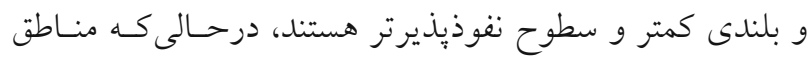

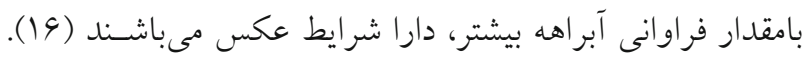

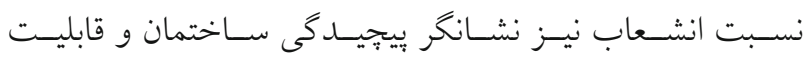

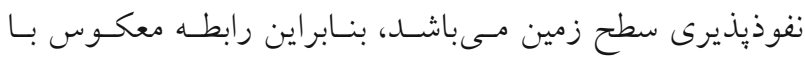
نفوذيذيرى حوزه آبخيز دارد (با، هQT).

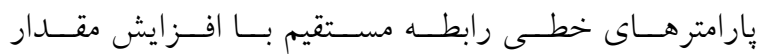

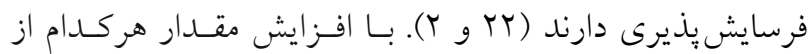
يار امترهاى خطى ظرفيت نفوذ كاهش يافته در نتيجه حساسـيت

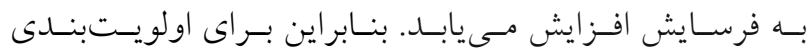

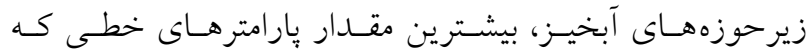
حساسيت به فرسايش بيشترى دارند با رتبه ل، و كمترين مقــدار با كمترين حساسيت به فرسايش رتبه با رتبـهبنـدى شــدانــ.

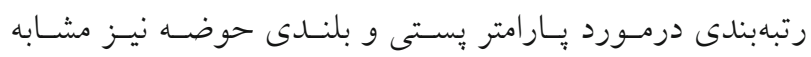

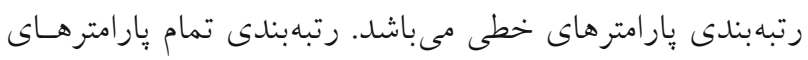
خطى در جدول (Y) آورده شده است. يارامترهاى شكل: در حوضههاى با مقدار فـاكتور شـكل كمتــر فرصت نفوذيذيرى كمتر بوده در نتيجه فرسايش بيشتر مى باشد.

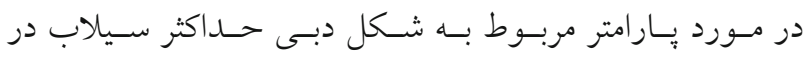

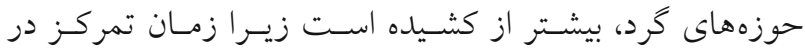

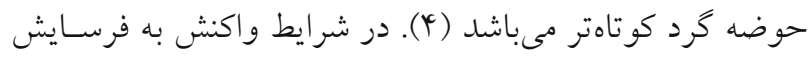
شاخص شكل حوضه نيز مشابه با فاكتور شكل رفتار مى كنـد. از

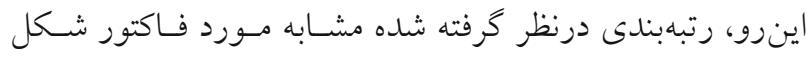

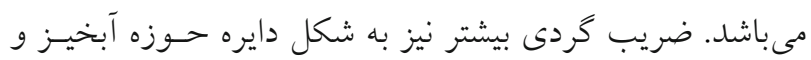
يستى بلندى متوسط تا زياد و نفوذيذيرى سطحى اشاره مى كنــ

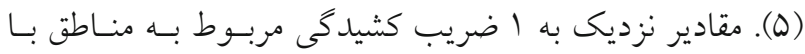
يستى بلندى خيلى كم درحالى كه از //ه تا 9/ه مربوط به مناطق

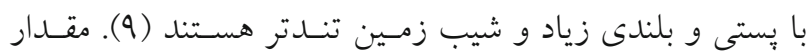

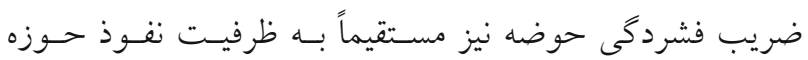

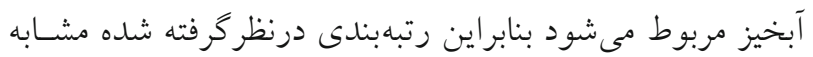


جدول Y. اولويتبندى زيرحوضهها بر مبناى پارامترهاى مورفومترى

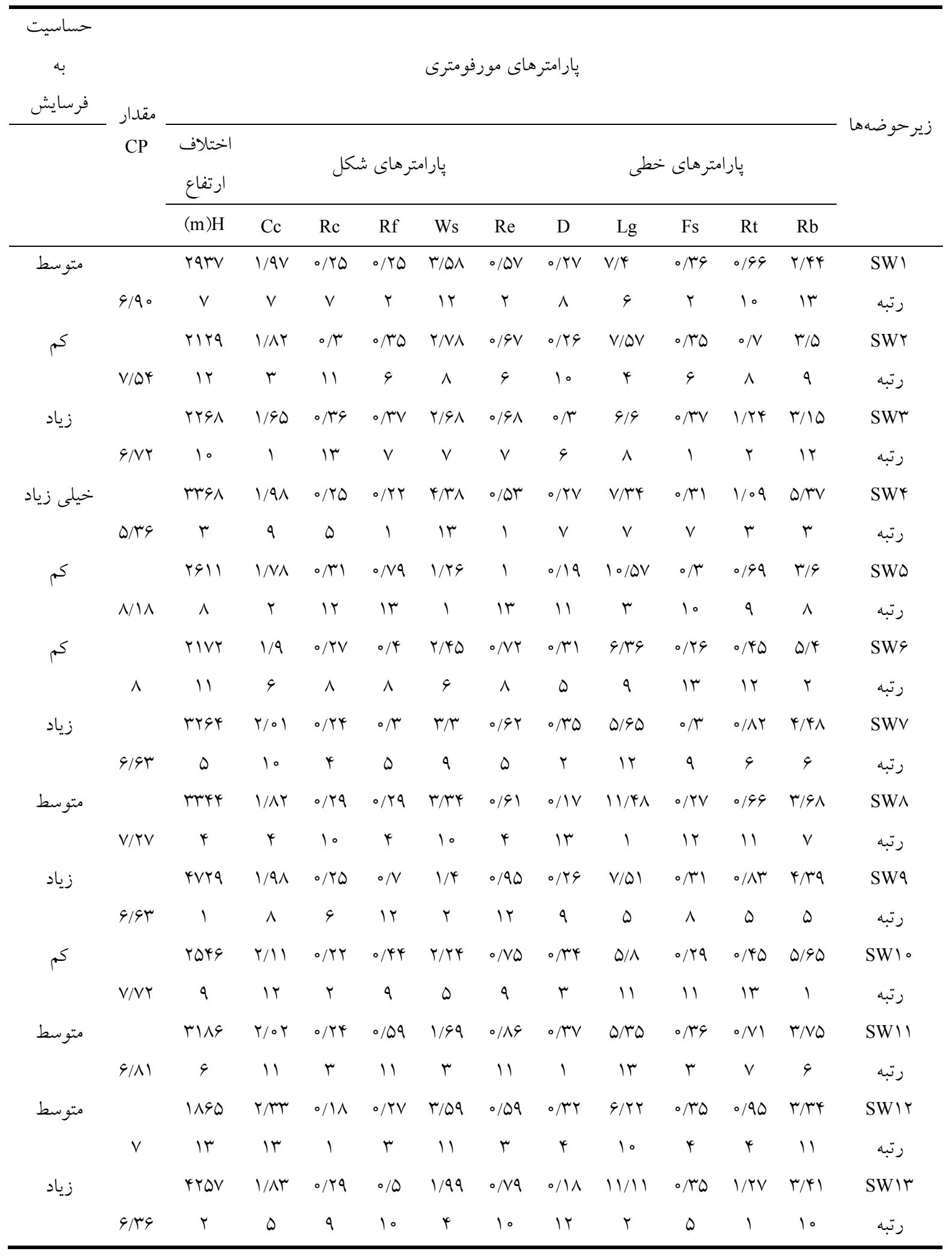



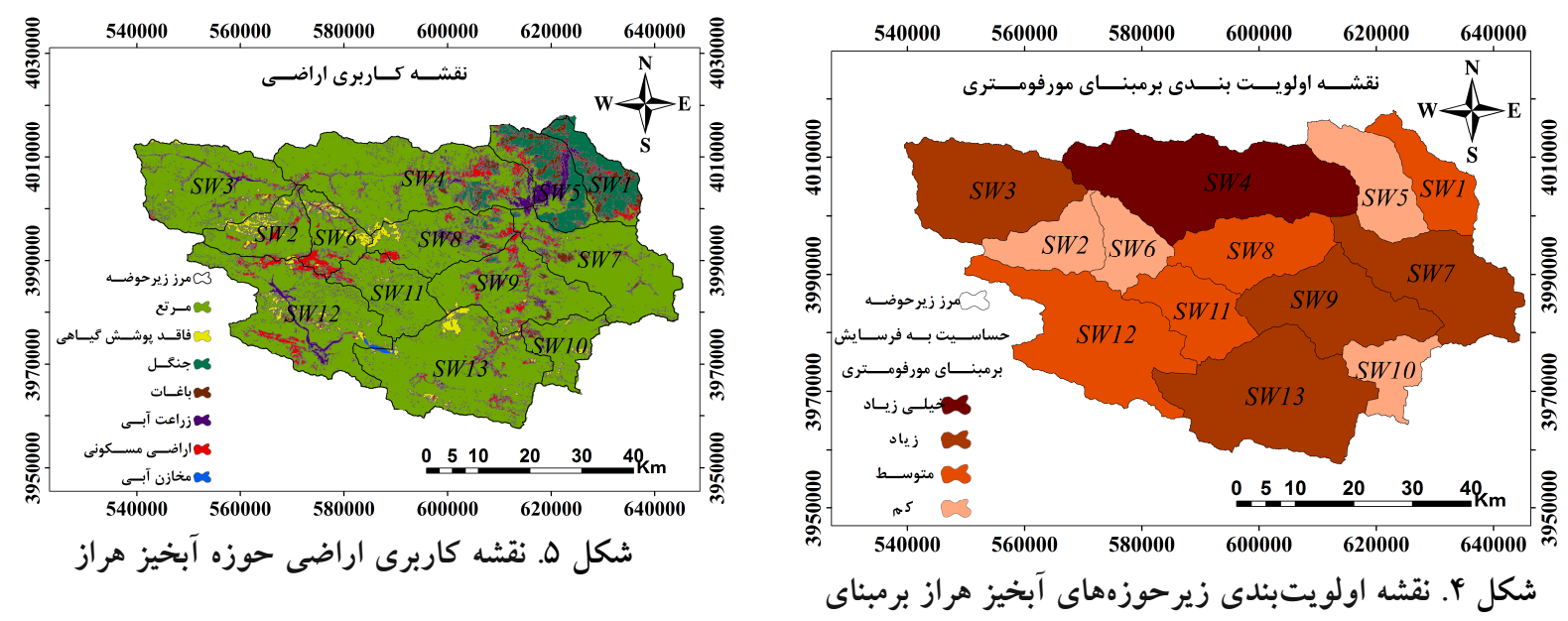

يارامترهاى مورفومترى

جدول r. ارزيابى نتايج طبقهبندى نوع كاربرى اراضى

\begin{tabular}{|c|c|c|c|c|c|}
\hline ضريب كايا & خطاى حذف شده & خطاى گماشته شده & دقت توليد كننده & دقت كاربر & نوع كاربرى \\
\hline \multirow{7}{*}{$\circ / \mathrm{VV}$} & $14 / 09$ & $M / \mu T$ & $19 / 41$ & $19 / 9 \Lambda$ & باغات \\
\hline & $\circ / \mathrm{VA}$ & 。 & $99 / Y r$ & 100 & مخازن آبى \\
\hline & TY/TG & $49 / 0^{\circ}$ & GV/VY & $\Delta r / \Delta \circ$ & زراعت آبى \\
\hline & $10 / v Q$ & $\circ$ & $\Lambda Y / r \Delta$ & 100 & اراضى جنشلى \\
\hline & $9 / 1 V$ & $\Delta \Lambda / \Psi \Lambda$ & $q \circ / \Lambda r$ & YI/DT & اراضى مرتعى \\
\hline & $r / 94$ & $V / O Y$ & $99 / 49$ & $9 r / 91$ & اراضى مسكونى \\
\hline & r T/Ar & $1 / 11$ & $9 \pi / 1 V$ & $91 / 19$ & اراضى فاقد يوشش كياهى \\
\hline
\end{tabular}

بهعلت داشتن تاج بوشش مانع برخورد مستقيم قطرات باران بـا

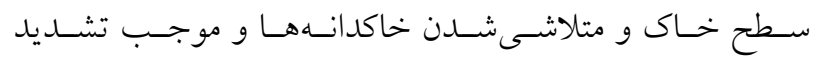

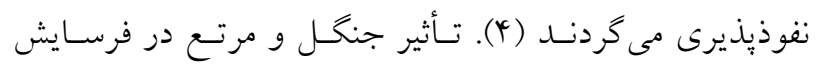

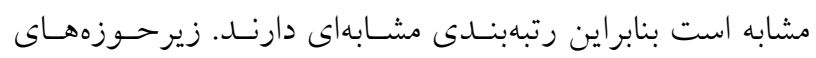
آبخيز با بيشترين درصد مساحت مرتع و جنگل بهعلت كمتـرين حساسيت به فرسايش رتبه سا و زيرحوزههاى با كمترين درصد مساحت مرتع و جنگل رتبه ا داده شدند. مساحت اراضى فاقد بوشش كيـاهى N/90 درصــ، زراعـت

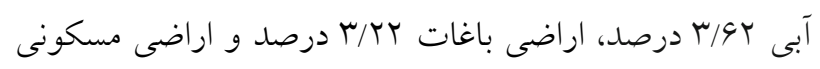

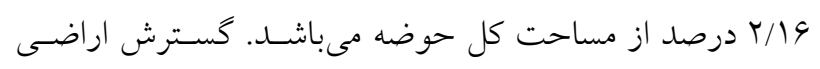

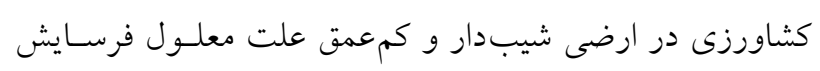
خاى در كشور مى باشد (Y). كسترش اراضسى مسـكونى باعـث
دارد (YN). بهعلاوه تفـاوت بوشـش گيـاهى تـأثير زيـادى روى رطوبت خاك، نفوذيذيرى، تبخيـر و تعـرق و فرسـايشيــيرى

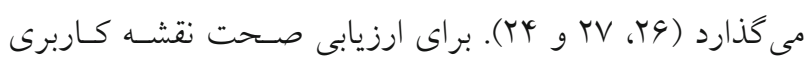

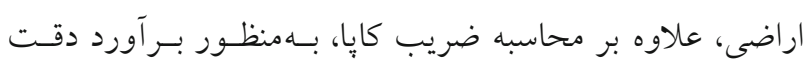
كلاسها از يارامترهاى ديخرى نظير دقت كاربرى، دقـت توليــ كننده، خطاى گماشته شده و خطاى حذف شده استفاده شد. كه اين يار امترها در جدول (r) ارائه شدهاند. نقشه كـاربرى اراضسى منطقه مورد مطالعه در شكل (ه) آورده شده است. مرتع اولين فاكتور غالـب در منطقـه مـورد مطالعـه اسـت و

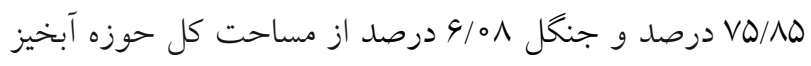
را مى يوشاند. مراتع بهعلت ساختار ريشـهاى متــراكم شــديداً در نحهداشت ذرات خاى به يكديخر تأثير مى خذارد. جنخل هـا نيـز 
جدول F. اولويتبندى زيرحوضهها بر مبناى پارامتر كاربرى اراضى

\begin{tabular}{|c|c|c|c|c|c|c|c|c|}
\hline حساسيت به فرسايش & $\mathrm{Cp}$ & فاقد يوشش كياهى & مسكونى اراضى & باغات & زراعت ابى & جنغل & مرتع & زير حوضهها \\
\hline & & O०Y & ه/A & $r \circ / T r$ & $r / N$ & $94 / 19$ & $V / \circ r$ & Swl \\
\hline \multirow[t]{2}{*}{ زياد } & $9 / \pi$ & ir & V & 1 & $r$ & 1 & 1 & رتبه \\
\hline & & IT/AY & $\Lambda / \Lambda$ & o/gY & $\circ / D Y$ & $0 / 01$ & $V V / \Lambda I$ & Swr \\
\hline \multirow[t]{2}{*}{ 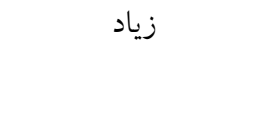 } & $\Delta / \Lambda$ & r & r & 10 & Ir & 0 & r & رتبه \\
\hline & & $T / T G$ & $T / 9 V$ & $0 / 94$ & $T / \Delta V$ & $\circ$ & $91 / 79$ & Swr \\
\hline \multirow[t]{2}{*}{ متوسط } & $\mathrm{V} / \mathrm{r}$ & V & ir & $\wedge$ & 4 & 。 & 11 & رتبه \\
\hline & &.$/ 99$ & $V / \circ Y^{4}$ & T/A & $Y / Y Y$ & $r / q$ & $\Lambda T / \circ \Delta$ & Sw \\
\hline \multirow[t]{2}{*}{ زياد } & $9 / 9$ & 10 & 4 & 0 & r & 11 & 4 & رتبه \\
\hline & & $0 / 01$ & $\varphi / \Lambda$ & $1 Y / \circ r$ & $19 / 4 \Lambda$ & YI/Ar & Tr/QV & Swd \\
\hline \multirow[t]{2}{*}{ زياد } & $9 / \pi$ & r & $\wedge$ & r & 1 & IT & r & رتبه \\
\hline & & $1 \% / 04$ & $19 / 01$ & $0 / 9 Y$ & $1 / 1 V$ & $\circ$ & $91 / 09$ & Swe \\
\hline \multirow[t]{2}{*}{ خيلى زياد } & $\mu / r$ & 1 & 1 & 11 & 10 & 。 & $r$ & رتبه \\
\hline & & سאום & $\Gamma / 9$ & $T / Y Q D$ & $1 / T V$ & $\circ / V G$ & $91 / 09$ & SwV \\
\hline \multirow[t]{2}{*}{ 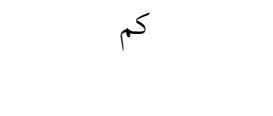 } & $9 / 9$ & 11 & 11 & 9 & 9 & 9 & ir & رتبه \\
\hline & & $Y / T 1$ & $V / 4 Y$ & $\varphi / 41$ & $r / \Delta Y$ & $1 / 4 y$ & VN/QG & SwA \\
\hline \multirow[t]{2}{*}{ خيلى زياد } & $0 / 0$ & 0 & 0 & r & 0 & 10 & 0 & رتبه \\
\hline & & $1 / 1 r$ & $V / A V$ & $r / 1$ & $1 / 90$ & $0 / M G$ & $\Lambda \varepsilon / \Gamma$ & Sw9 \\
\hline \multirow[t]{2}{*}{ زياد } & $9 / 9$ & 9 & r & q & v & $\wedge$ & $\wedge$ & رتبه \\
\hline & & $Q / V I$ & $1 / \wedge 9$ & $T / T Q$ & $1 / 79$ & \% & M/^S & Swl。 \\
\hline \multirow[t]{2}{*}{ متوسط } & $\mathrm{V} / \mathrm{\Lambda}$ & r & ir & v & $\wedge$ & V & 9 & رتبه \\
\hline & & $1 / 9 T$ & $\varphi / 1 r$ & $0 / 01$ & $0 / 41$ & $\circ$ & $q r / \Delta r$ & $\mathrm{Sw} 11$ \\
\hline \multirow[t]{2}{*}{ 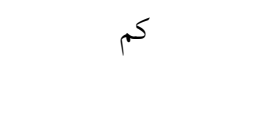 } & $9 / r$ & $\wedge$ & 9 & ir & ir & $\circ$ & ir & رتبه \\
\hline & & $4 / 19$ & N/IV & $0 / 0 Y$ & $r / \Lambda \Delta$ & 。 & $\Lambda \Gamma / \Lambda$ & SwIr \\
\hline \multirow[t]{2}{*}{ خيلى زياد } & $0 / 1$ & r & r & ir & $r$ & 。 & V & 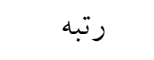 \\
\hline & & $4 / 9$ & $\varphi / \circ \Lambda$ & ०/AG & $\circ / V$ & O/० & $19 / N Y^{c}$ & Swlr \\
\hline متوسط & $\Lambda / r$ & $r$ & 10 & 9 & 11 & 9 & 10 & رتبه \\
\hline
\end{tabular}

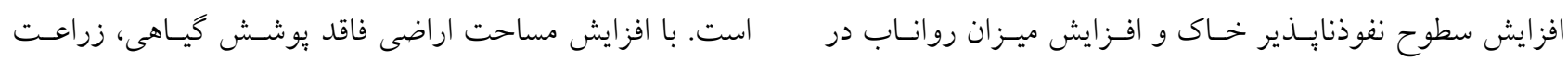

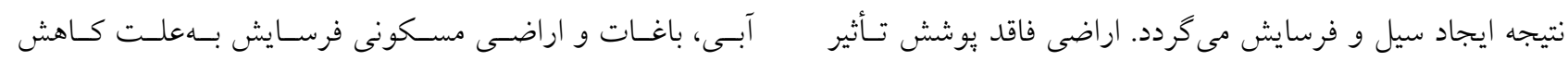

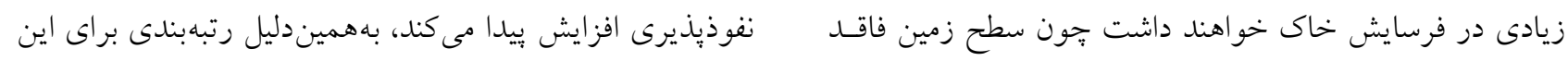

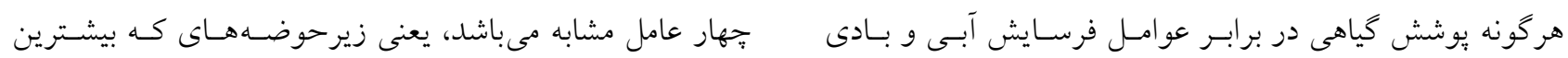


نشريه علوم آب و خاك (علوم و فنون كشاورزى و منابع طبيعى) / سال بيستم / شماره هفتادو هفتم/ باييز ههب1

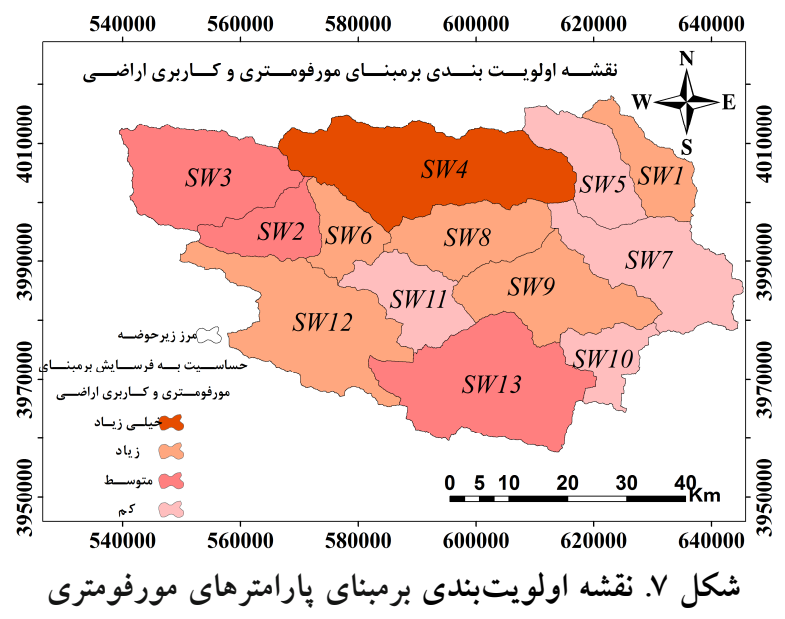

و كاربرى اراضى بندين

حوضه تأثير فراوان دارند. نحوه استفاده از اراضى هم در اين روابـط

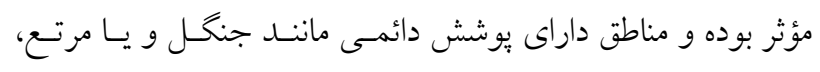

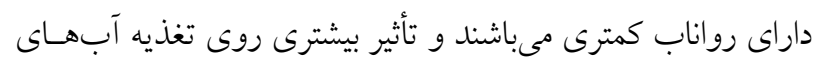

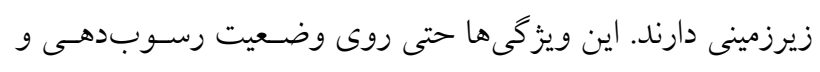

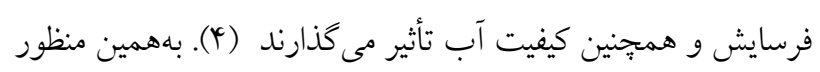

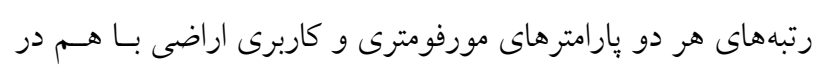

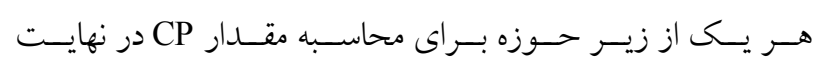

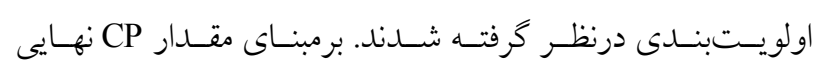

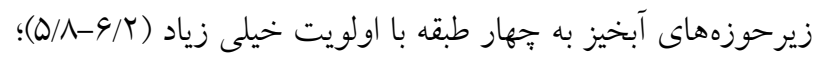

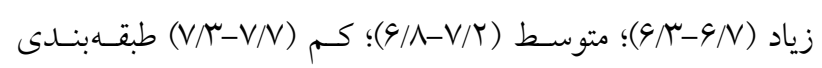

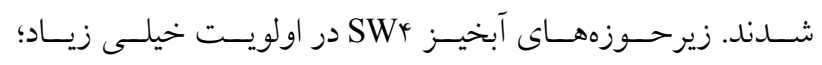

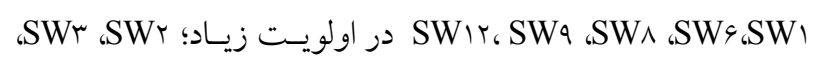

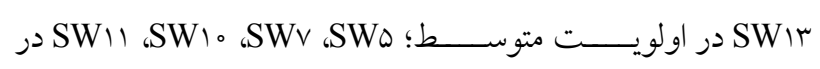

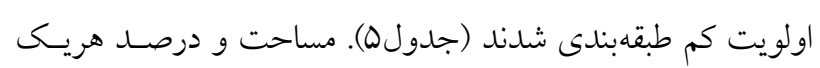

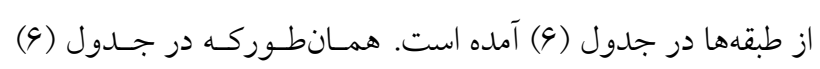

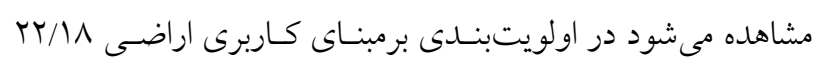

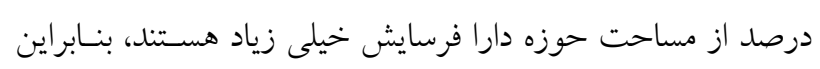

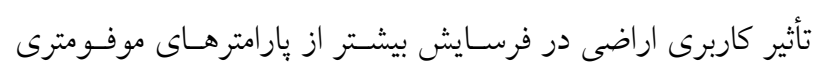
است. نقشه نهايى اولويتبندى زيرحوزههاى آبخيـز برمبنـاى تـأثير

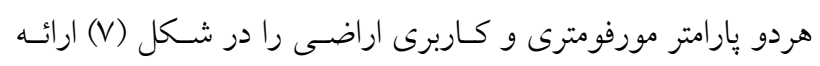
كرديد.

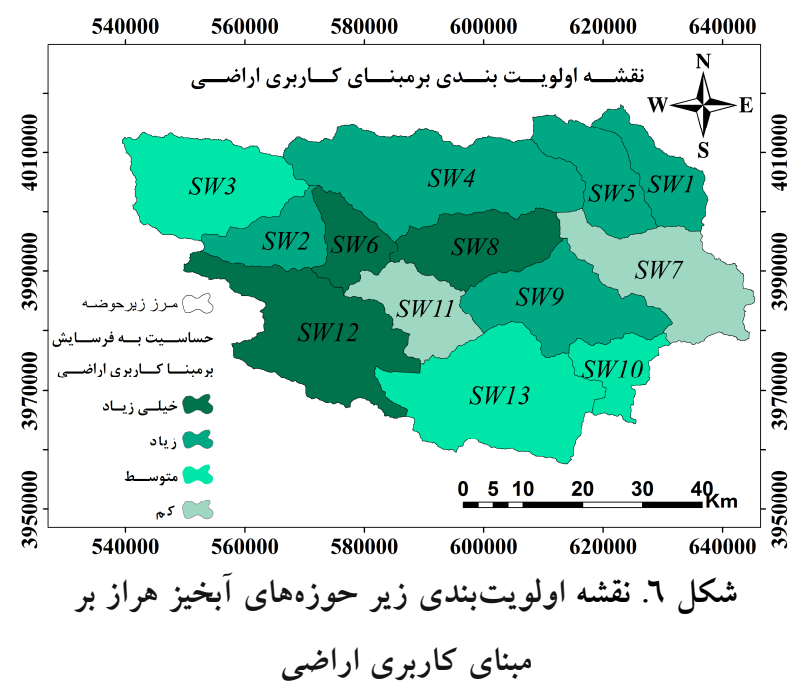

مساحت را دارند بهعلت فرسايش زياد رتبه ا و زيرحوضههـاى

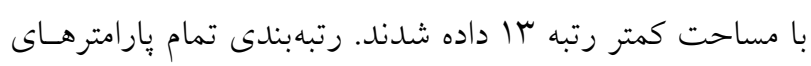
مربوط به كاربرى اراضى در جدول (؟) آورده شده است.

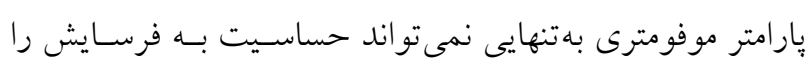

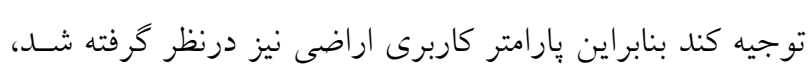

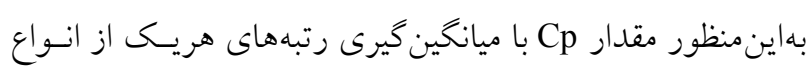

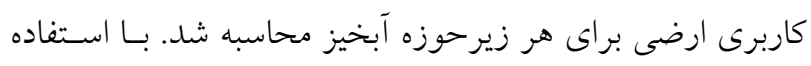

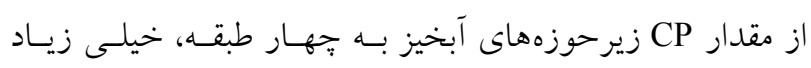

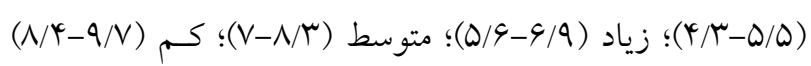

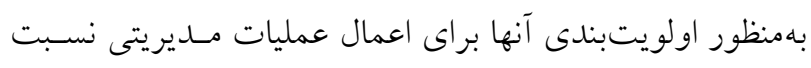

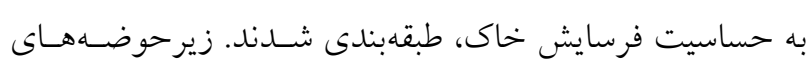

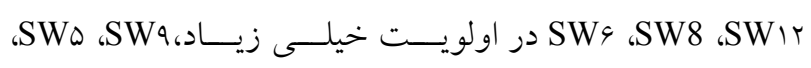

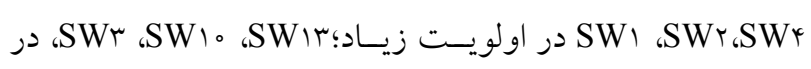

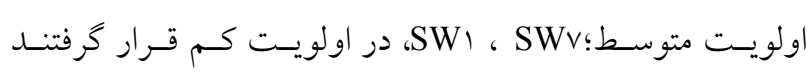

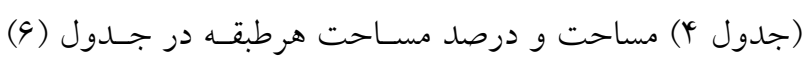

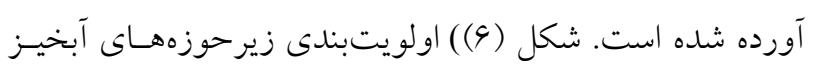
را برمبناى آناليز كاربرى اراضى نشان مىدهد.

اولويتبندى برمبناى تأثير هردو پارامتر مورفومترى و كاربرى اراضى ويزگى هاى فيزكى حوضه، روى ضريب رواناب و بـيلان آبـى يـى 


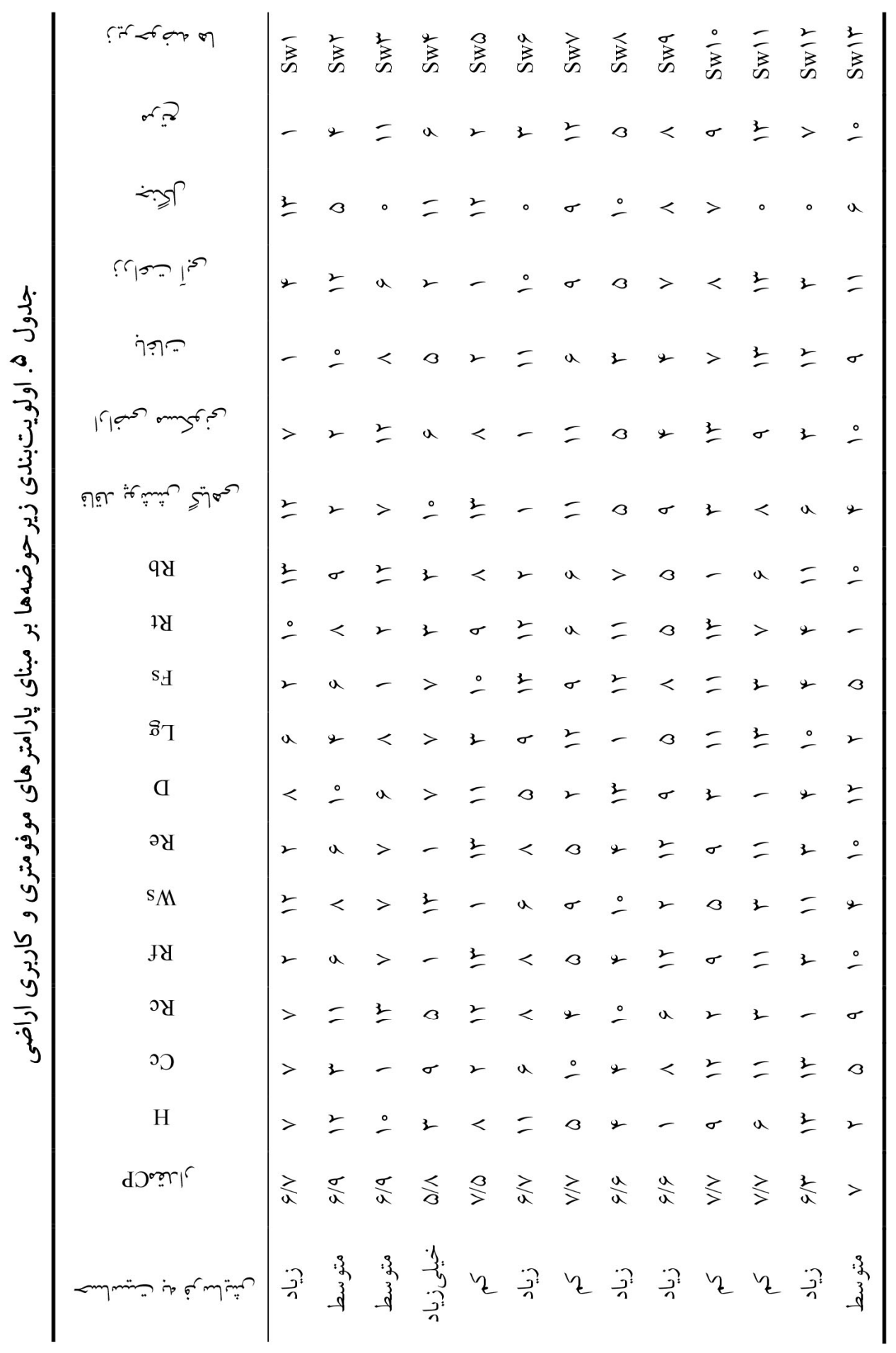


جدول 7. مساحت و درصد طبقهبندى حساسيت به فرسايش

\begin{tabular}{|c|c|c|c|c|}
\hline درصد & مساحت ( & تعداد زيرحوضه & حساسيت به فرسايش & مبناى اولويتبندى \\
\hline $14 / \Lambda$ & $099 / 9$ & 1 & خيلى زياد & \\
\hline $40 / 14$ & $1909 / \mathrm{V}$ & 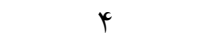 & زياد & مورفومترى \\
\hline rV/VV & $1111 / 9$ & $r$ & متوسط & \\
\hline $19 / \pi$ & $909 / 0 \Lambda$ & 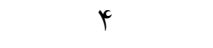 & كم & \\
\hline$r Y / \Lambda \Lambda$ & $\Lambda 94 / 4 \Delta$ & r & خيلى زياد & \\
\hline $\mathrm{MV} / \circ \mathrm{G}$ & $\mid F q T / F D$ & 0 & زياد & كاربرى اراضى \\
\hline TS/KY & $1094 / V 1$ & r & متوسط & \\
\hline $\mid y / \mu y$ & $\Delta V V / 9 V$ & r & كم & \\
\hline $14 / 11$ & $099 / 09$ & 1 & خيلى زياد & \\
\hline MY/As & $\mid y \circ \mu / r$ & 0 & زياد & مورفومترى و \\
\hline$T V / r$ & $1099 / 9$ & r & متوسط & كاربرى اراضى \\
\hline$r M / 0 Y^{r}$ & $9 Y N / 10$ & $r$ & كم & \\
\hline
\end{tabular}

مجموعه عوامل زيسـت محيطى در زمينـه فرسـايش يـذيرى و كاربرى اراضى نشان مىدهد كه دخالت انسان در جرخه طبيعت از طريق تخريب بوشش كياهى در عرصه آبخيـزدارى، كـاربرى غير اصولى اراضسى، توسـعه سـطوح غيرقابـل نقـوذ آن احتمـال فرسايش يذيرى و همجنين سـيل خيـزى را در منـاطق كونـاكون افزايش دادهاسـت. بـههمـين منظـور يـارامتر كـاربرى اراضسى و

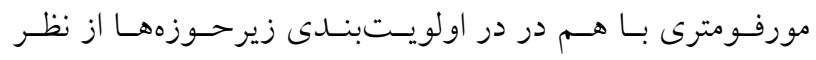
حساسيت به فرسايش مدنظر قرار كرفتند. نتـايج اولويـتبنـدى سا زيرحوزه آبخيز هراز نشان داد كه در اولويتبندى بر مبنـاى مورفـومترى زيرحوضـه SW4، و در اولويـت بنـدى برمبنـاى كاربرى اراضى زيرحوضسههـاى SW8، SW6 SW12 در خـروه اولويت خيلى زياد از نظر حساسيت به فرسايش قرار كرفتهانـد.

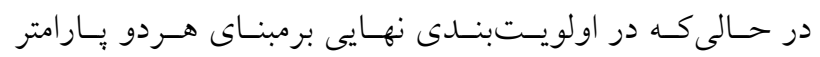
مورفومترى و كاربرى اراضى زيرحوضه SW4 به عنـوان منطقـه

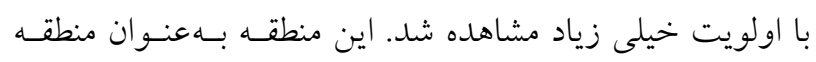
بسيار بحرانى از لحاظ حساسيت بسيار زياد به فرسـايش خـاى شناسايى شد، بنابراين بايد در اولويت اول براى اجراى عمليـات

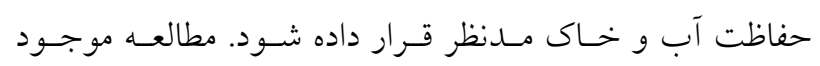

نتيجه گيرى

براى آناليز مورفومترى حوزه آبخيز هـــاز، ارزيـابى بِارامترهـاى مورفومترى و كاربرى اراضى و تأثير آن روى حساسـيت خـاى به فرسايش با استفاده از نرمافزار GIS و RS انجام شد. شناسايى مناطق بحرانى از نظر حساسـيت بـه فرسـايش خــاك بـهمنظـور اجراى عمليات حفاظت آب و خاك ضـرورى مسىباشـد. نتـايج اين تحقيق نشان داد كه با تلفيـق GIS و عوامـل هيـدرولوزيك

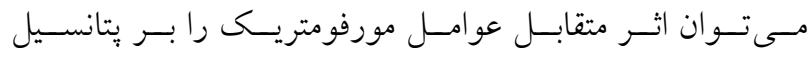
فرسايش يذيرى حوزههاى آبخيز مورد بررسى قـرار داد. سـامانه اطلاعات جغرافيايى GIS يكى از ابزارهــاى قدرتمنــ تحليـل و

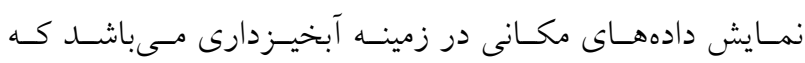

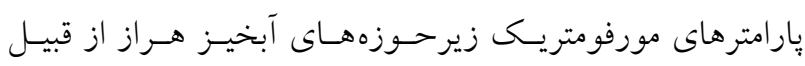
يارامترهاى نسبت انشعاب، تراكم زهكشى، فراوانى آبراهه، بافت زهكشى، فاكتور شكل، ضريب كردى، ضريب فشردگى، ضريب كشيدگى، طـول جريـان روى سـطح زمسين، شـاخص شـكل و اختلاف ارتفاع حوضه براى هركدام از سا زيرحوضه در محسيط و و با تكيه بر نقشه مدل رقومى ارتفاع منطقه استخراج شدند

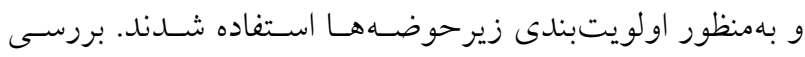




$$
\begin{aligned}
& \text { استفاده از نرمافزار GIS را در اولويتبندى زيرحوزههاى آبخيـز حفاظت منابع آب و خاى را اثبات مىكند. }
\end{aligned}
$$

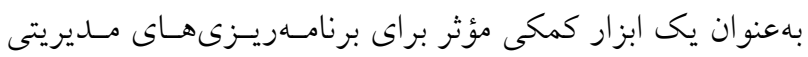

$$
\begin{aligned}
& \text { منابع مورد استفاده } \\
& \text { ا. آمانى، م.، و ع. نجفى نزاد. سوسا اولويتبندى زيرحوزهها با استفاده از آناليز مورفومترى، فنون سنجش از دور و GIS، حسوزه آبخيـز }
\end{aligned}
$$

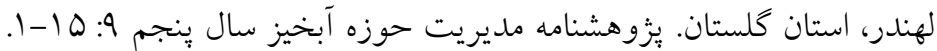

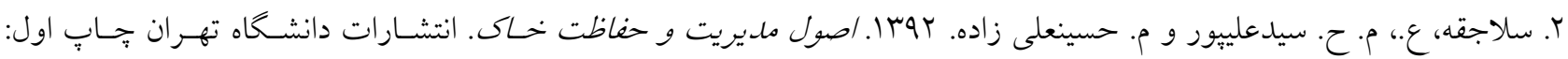

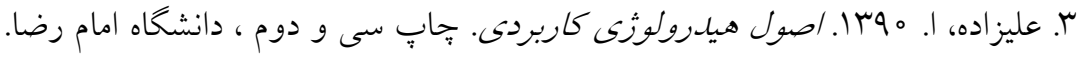

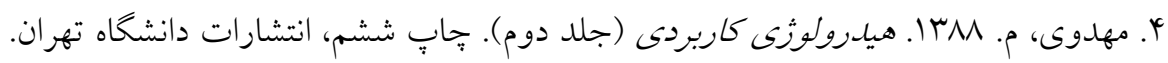

5. Altaf, S., G. Meraj and S. A. Romshoo. 2014. Morphometry and land cover based multi-criteria analysis for assessing the soil erosion susceptibility of the western Himalayan watershed. Environ. Monit Assess. 186(12): 8391-8412.

6. Amba S., L. Nandagiri, S. Thokchom and M.V. S. Rajesh. 2005. Land use-land cover mapping using satellite data for a forested watershed, Udipi district, Karnataka state, India. J. of the Indian Soci. of Remote Sensing 33(2): 233238.

7. Bayramin, I., O. Dengiz, O. Baskan and M. Parlak. 2003. Soil erosion assessment with ICONA model: Case study: Beypazari area. Turkish J. of Agr. and Forestry 1 (27): 105-116.

8. Chen, J., A. A. Hill and L. D. Urbano. 2009. A GIS-based model for urban flood inundation. J. Hydrol. $373: 184-192$.

9. Dar, R.A, R. Chandra, and S.A. Romshoo. 2013. Morphotectonic and Lithostratigraphic analysis of Intermontane Karewa basin of Kashmir Himalayas, India. J. of Mountain Sci. 10(1): 1-15.

10. Gajbhiye, S., S. K. Mishra and A. Pandey. 2014. Prioritizing erosion-prone area through morphometric analysis:an RS and GIS perspective. Applied Water Sci. 4(1): 51-61.

11. Harlin, J. M and C. Wijeyawickrema. 1985. Irrigation and groundwater depletion in Caddo county, Oklahoma. J. Am. Water Resour. As. 21(1): 15-22.

12. Horton, R. E. 1932. Drainage basin characteristics. Transactions of the American Geophysical Union. 13(1): 350361.

13. Horton, R. E. 1945. Erosional development of streams and their drainage basins: Hydrophysical approach to quantitative morphology. Geol Soc. Am. Bull 56: 275-370.

14. Howard, A. D. 1990. Role of hypsometry and planform in basin hydrologic response. Hydrological Processes 4(4): 373-385.

15. Javed, A, M. Y Khanday and R. Ahmed. 2009. Prioritization of watersheds based on morphometric and landuse analysis using RS and GIS techniques. J. of the Indian soci. of Remote Sensing 37: 261-274.

16. Jee Omar, P. 2015. Geomatics Techniques based significance of morphometric analysis in prioritization of watershed. Int. J. of Enhanced Res. in Sci. Technol. \& Eng. 4(1): 24-13.

17. Joshi, PK., G. S. Rawat, H. Padaliya and P. S. Roy. 2005. Land use/land cover identification in an Alpine and arid region (Nubra valley, Ladakh) using satellite remote sensing. J. of the Indian soci. of Remote Sensing 33(4): 371380.

18. Kavian, A., A. Azmoodeh and K. Solaimani. 2013. Deforestation effects on soil properties, runoff and erosion in northern Iran. Arabian J. of Geosciences. doi:10.1007/s12517-013-0853-1.

19. Kumar, R., S. Kumar, A. K. Lohani, R. K. Nema and R. D. Singh. 2000. Evaluation of geomorphological characteristics of a catchment using GIS. GIS India 9(3): 13-17.

20. Luo, W. 1900. Quantifying groundwater- sapping landforms with a hypsometric technique. J. Geophys Res. 105: 1685-1694.

21. Mahajan, S. and P. Panwar. 2005. Land use changes in Ashwani Khad watershed using GIS techniques. J. of the Indian soci. of Remote Sensing 33(2): 227-232.

22. Nooka R., K, YK. Srivastava Rao, V. Venkateshwara, E. Amminedu and K. S. R. Murthy. 2005. Check dam positioning by prioritization of micro-watersheds using SYI model and morphometric analysis- Remote Sensing and GIS perspective. J. of the Indian soci. of Remote Sensing 33(1): 25-38. 
23. Pirasteh, S., H. O. Safari, B. Pradhan and I. Attarzadeh. 2010. Litho morphotectonics analysis using Landsat ETM data and GIS techniques: Zagros Fold Belt (ZFB), SW Iran. Int. Geoinformatics Res. and Development J. 1(2): 9-1.

24. Pradhan, B. 2010. Flood susceptible mapping and risk area estimation using logistic regression, GIS and remote sensing. J. Spatial Hydrology 9(2): 1-18.

25. Rakesh, K., A. K. Lohani, C. Sanjay and R. K. Nema. 2000. GIS based morphometric analysis of Ajay river basin upto Srarath gauging site of South Bihar. J. of Applied Hydrology 14(4): 45-54.

26. Rashid, I and S. A. Romshoo. 2012. Impact of anthropogenic activities on water quality of Lidder River in Kashmir Himalayas. Environ Monit Assess 185: 4705-4719.

27. Romshoo, S. A, S. A. Bhat and I. Rashid. 2012. Geoinformatics for assessing the morphometric control on hydrological response at watershed scale in the Upper Indus Basin. J. of Earth System Sci. 121(3): 659-686.

28. Rosenqvist, A. and C. M. Birkett. 2002. Evaluation of JERS -1 SAR mosaics for hydrological applications in the Congo river basin." Int. J. Remote Sensing 23(7): 1283-1302.

29. Shamsudheen, M., G. S. Dasog and N. B. Tejaswini. 2005. Land use/land cover mapping in the coastal area of North Karnataka using remote sensing data. J. of the Indian society of Remote Sensing 33(2): 253-257.

30. Sharma, R., B. Sahai and R. L. Karale. 1985. Identification of erosion-prone areas in a part of the Ukai catchment. PP. 121-126. In: Proceedings, sixth Asian conference on remote sensing. Hyderabad, India.

31. Srinivasa, R. K. and K. D. Nagesh. 2011. Classification of microwatersheds based on morphological. Hydroenviron. Res. 5: 101-109.

32. Strahler, A. N. 1964. Quantitative geomorphology of drainage basins and channel networks. PP. 4-11. In: V. T. Chow (Ed.), Handbook of applied hydrology.

33. Suresh, M., S. Sudhakar, K. N. Tiwari and V. M. Chawdary. 2004. Prioritization of watershed using morphometric parameters and assessment of surface water potential using RS. J. of the Indian society of Remote Sensing 32: 249259.

34. Thakkar, A. K. and S. D. Dhiman. 2007. Morphometric analysis and prioritization of miniwatersheds in a Mohr watershed, Gujarat using remote sensing and GIS techniques. J. of the Indian society of Remote Sensing 35 (4): 313-321.

35. Todorovski, L. and S. Džeroski. 2006. Integrating knowledgedriven and data-driven approaches to modeling. Ecol. Model. 194(1): 3-13. 


\title{
Prioritizitzation of Haraz sub-watersheds in order to Soil and Water Conservation Practices Based on Morphometric and Land Use Characteristics
}

\author{
M. Fallah Sourki ${ }^{1}$, A. Kavian ${ }^{1^{*}}$ and E. Omidvar²
}

(Received: July 1-2015 ; Accepted : April 20-2016)

\begin{abstract}
Prioritization of sub-watersheds is very important and necessary in order to implement soil and water conservation practices. This study has prioritized 13 sub-watersheds based on morphometric and land use characteristics using RS and GIS techniques in Haraz watershed to identify erosion-prone sub-watersheds. Morphometric characteristics including bifurcation ratio, drainage density, stream frequency, drainage texture, form factor, basin circularity, compactness coefficient, elongation ratio, length of overland flow, shape index, and basin relief were considered in morphometric analysis. Land use map was classified into seven classes of forest, water-body, irrigated farming, bare land, rangeland, orchard and residential area. Finally, sub-watersheds were classified into four categories as very high, high, medium and low in terms of priority for soil conservation. On the basis of morphometric analysis sub-watershed WS-4 was considered as high priority, whereas according to land use analysis, sub-watersheds WS-6, WS-8, WS-12 were in class of high priority. Sub-watershed WS-4 was categorized as a very high priority class based on the integration of morphometric and land use analysis. This region was identified as critical region therefore should be considered as priority class for implementation of soil and water conservation practices.
\end{abstract}

Keywords: conservation practices, erosion-prone, GIS, RS.

1. Dept. of Watershed Management Eng., Faculty of Natural Resource, Sari Agr. Sci. and Natural Resource Univ., Sari, Iran.

2. Dept. of Watershed Manage. Eng., Kashan Univ., Kashan, Iran.

*: Corresponding Author, Email: a.kavian@sanru.ac.ir 